BIOFARM

Jurnal Ilmiah Pertanian

ISSN Print: 0216-5430; ISSN Online: 2301-6442

Vol. 16, No. 2, Oktober 2020

\title{
Potensi Olahan Sagu Dalam Mendukung Diversifikasi Pangan Di Desa Poreang Kabupaten Luwu Utara
}

\author{
The Potential of Processed Sago in Support of Food Diversification in Poreang \\ Village, North Luwu Regency
}

\author{
Muhammad Arhan Rajab* dan Munisya \\ Program Studi Agribisnis, Fakultas Pertanian, Universitas Cokroaminoto Palopo \\ *Korespondensi Penulis: arhanrajab@gmail.com
}

\begin{abstract}
ABSTRAK
Penelitian ini bertujuan untuk mengetahui bagaimana meningkatkan jumlah produk diversifikasi pangan lokal berbahan dasar sagu. Jenis penelitian ini adalah penelitian deskriptif. Desain penelitiannya adalah penelitian survey yaitu penelitian yang mengambil sampel dari suatu populasi dan menggunakan kuesioner sebagai alat bantu pengumpulan data yang pokok. Teknik pengumpulan data dilakukan melalui wawancara, observasi, dan pencatatan.Data yang digunakan dalam penelitian ini adalah data primer dan data sekunder.Data primer diperoleh melalui wawancara langsung dengan responden sedangkan data sekunder diperoleh secara tidak langsung seperti buku.Hasil penelitian ini menunjukkan bahwa diversifikasi pangan lokal berbahan dasar sagu UKM Senang Hati di Desa Poreang Kecamatan Tana Lili Kabupaten Luwu Utara yaitu bacci laung dan kerupuk sagu.
\end{abstract}

Kata kunci: potensi, olahan, sagu, diversifikasi, pangan

\begin{abstract}
This study aims to determine how to increase the number of diversified local food products made from sago. This type of research is descriptive research. The research design is survey research, namely research that takes a sample from a population and uses a questionnaire as a primary data collection tool. Data collection techniques are carried out through interviews, observation, and recording. The data used in this study are primary data and secondary data. Primary data is obtained through direct interviews with respondents while secondary data is obtained indirectly like books. The results of this study indicate that food diversification Local UKM Senang Hati's sago-based ingredients in Poreang Village, Tana Lili District, North Luwu Regency, namely bacci laung and sago crackers.
\end{abstract}

Keywords: potential, processed, sago, diversification, food

\section{PENDAHULUAN}

Tanaman sagu (Metroxylon sp) merupakan salah satu tanaman penghasil karbohidrat yang penting kedudukannya sebagai bahan makanan sesudah padi, jagung, dan umbi-umbian. Sagu memiliki kandungan karbohidrat (kalori) yang memadai dan memiliki kemampuan substitusi pati sagu dalam industri pangan (Hayati et all., 2014)

Tanaman sagu sangat potensial untuk dikembangkan sebagai bahan pangan alternatif bagi masyarakat Indonesia selain padi. Pasalnya, sagu menghasilkan pati kering sebagai bahan pangan sumber karbohidrat. Meskipun memiliki potensi sebagai bahan pangan sumber karbohidrat alternatif non beras, namun hingga 2009 angka konsumsi sagu masyarakat Indonesia masih rendah yaitu $0,41 \mathrm{~kg} / \mathrm{kapita} / \mathrm{tahun}$.

Potensi sagu di Indonesia dari sisi luas areal sangat besar. Sekitar $60 \%$ areal sagu dunia berasal dari di Indonesia. Data yang ada menunjukkan bahwa areal sagu Indonesia menurut Prof. Flach mencapai 1,2 juta ha dengan produksi berkisar 8,413,6 juta ton per tahun, dan sekitar $90 \%$ berada di Papua. Sagu merupakan salah satu makanan pokok beberapa daerah di Indonesia Bagian Timur, bukan hanya di Provinsi Sulawesi Selatan (daerah Luwu), tapi juga di Papua, Maluku, Sulawesi Utara, dan sejumlah daerah di Nusa Tenggara. 
Penelitian ini dilakukan untuk menyelesaikan suatu masalah yang dihadapi oleh Usaha Kecil Menengah (UKM) produk sagu di Desa Poreang Kecamatan Tana Lili Kabupaten Luwu Utara mengenai diversifykasi pangan berbahan dasar sagu yang banyak mengalami keterpurukan, misalnya yaitu kurangnya pengenalan produk ke masyarakat maupun bisnis yang sedang digeluti pertanda kurangnya melakukan promosi atau promosi yang dilakukan mengalami kegagalan, kurangnya tenaga kerja yang ada di sekitar kita yang memiliki keahlian dalam hal diversifikasi pangan berbahan dasar sagu, kurang dilakukannya pemasaran yang mengakibatkan kerugian, dan banyaknya pesaing yang ada di sekitar kita yang mampu membuat bisnis yang digeluti mengalami kebangkrutan.

Untuk itu dengan adanya diversifikasi pangan berbahan dasar sagu Usaha Kecil Menengah (UKM) dapat memiliki banyak pengetahuan mengenai diversifikasi pangan sehingga tercipta produk sagu yang baru yang dapat mengembangkan suatu bisnis dan menghasilkan produk sagu yang lebih kreatif. Diversifikasi pangan berbahan dasar sagu yang menghasilkan produk yang bagus dan lebih kreatif dapat mempengaruhi pemasaran, persaingan, dan promosi.

Berdasarkan latar belakang masalah yang diuraikan diatas maka sangat penting melakukan penelitian dengan judul potensi olahan sagu dalam mendukung diversifikasi pangan di Desa Poreang Kecamatan Tana Lili Kabupaten Luwu Utara.

\section{BAHAN DAN METODE}

Lokasi penelitian ini ditentukan secara sengaja (Purposive Method). Lokasi penelitian adalah Desa Poreang Kecamatan Tana Lili Kabupaten Luwu Utara, dengan pertimbangan bahwa lokasi tersebut merupakan salah satu lokasi yang melakukan diversifikasi pangan lokal berbahan dasar sagu dimana penelitian ini dilakukan mulai bulan Maret 2019-April 2019.
Populasi adalah wilayah generalisasi yang terdiri atas objek atau subjek yang mempunyai kuantitas dan karakteristik tertentu yang ditetapkan oleh peneliti untuk dipelajari dan kemudian ditarik kesimpulannya (Sugiyono, 2012).

Sampel adalah sebagian atau wakil populasi yang di teliti. Apabila subjeknya kurang dari 100 lebih baik diambil semua. Sebaliknya jika subjeknya lebih besar dari 100 dapat diambil antara $10-15 \%$ atau 20 25\% (Arikunto, 2013).

Adapun yang menjadi sampel dalam penelitian yang dilakukan di Desa Poreang Kecamatan Tana Lili Kabupaten Luwu Utara yaitu:

1. Pemilik UKM Senang Hati berjumlah 1 orang

2. Pengolah produk diversifikasi pangan (Karyawan) berjumlah 8 orang

3. Konsumen berjumlah 15 orang

Teknik pengambilan sampel penelitian ini dilakukan dengan menggunakan metode purposive sampling (penetapan sampling) yang merupakan teknik pengambilan sampel yang memberikan kesempatan yang sama dengan populasi untuk dijadikan sampel.

Analisis data dalam penelitian ini menggunakan metode deskriptif yang digunakan untuk menggambarkan bagaimana masalah yang terjadi pada masa sekarang atau yang sedang berlangsung yang bertujuan untuk mendeskripsikan apa-apa yang terjadi sebagaimana mestinya pada saat penelitian dilakukan.

\section{HASIL DAN PEMBAHASAN Sejarah Berdirinya UKM Senang Hati}

UKM adalah usaha kecil menengah yang bertujuan untuk mendukung diversifikasi pangan untuk meningkatkan hasil olahan berbahan dasar sagu dan membuka lapangan pekerjaan bagi masyarakat Desa Poreang Kecamatan Tana Lili yang memiliki pendidikan minim. Usaha kecil menengah (UKM) adalah usaha yang bergerak di bidang industri dan merupakan usaha yang fokus meningkatkan hasil olahan berbahan dasar sagu 
seperti bagea, kapurung, dan sinole. UKM senang hati menjadikan ketiga produk tersebut sebagai salah satu produk unggulan karena bahan baku utama dalam membuat bagea, kapurung, dan sinole yaitu sagu, dimana bahan baku tersebut cukup banyak tersedia di daerah Desa Poreang Kecamatan Tana Lili Kabupaten Luwu Utara.

Sekitar tahun 2013 di Desa Poreang Kecamatan Tana Lili didirikan suatu usaha kecil menengah (UKM) dimana usaha ini memproduksi berbagai macam olahan berbahan dasar sagu antara lain bagea, kapurung, dan sinole. Pemilik UKM Senang Hati bernama Halijah dan memiliki karyawan sebanyak 8 orang yang bisa bekerja sama untuk meningkatkan usaha kecil menengah (UKM) yang berada di Desa Poreang Kecamatan Tana Lili Kabupaten Luwu Utara. Setiap karyawan memiliki keahlian masing-masing sesuai dengan bidang yang menjadi tanggung jawabnya agar semua kegiatan yang ada di usaha kecil menengah (UKM) di Desa Poreang Kecamatan Tana Lili dapat terorganisir secara maksimal.

\section{Diversifikasi Pangan Berbahan Dasar Sagu}

\section{a. Bagea}

Bagea adalah kue kering yang terbuat dari olahan sagu. Bagea adalah kue tradisional khas Maluku, Maluku Utara, dan Kota Palopo, Sulawesi Selatan, Indonesia. Bagea biasanya berbentuk bulat dan warnanya cokelat pucat. Bagea sifatnya keras, dan susah dimakan, orang yang tak terbiasa memakannya akan kesulitan. Biasanya Bagea disantap dengan teh atau kopi. Bahan-bahan untuk membuat Bagea adalah gula halus, biji kenari yang telah dicincang, tepung sagu, minyak sayur, tepung terigu yang telah diayak, kacang tanah yang dicincang halus, kayu manis bubuk, dan cengkih bubuk.

Proses pengolahan bagea di UKM Senang Hati masih secara tradisional. Prosesnya hanya mencampurkan pati sagu, santan, gula pasir, telur, kenari, kayu manis sampai membentuk adonan, dicetak kemudian dipanggang.

Proses pemanggangan, menggunakan sumber panas langsung, menggunakan bahan bakar seperti oven hock. Pemerintah setempat sangat mendukung usaha kecil menengah (UKM) pengolahan kue bagea dengan memberikan bimbingan cara pengolahan yang baik dan higienis serta sering diikutsertakan dalam kegiatankegiatan pameran lokal.

Pemasaran kue Bagea yang dilakukan oleh UKM Senang Hati dengan cara menjual ke toko-toko kue yang ada di Kabupaten Luwu Utara. Perbaikan fasilitas produksi masih diperlukan melalui dukungan dana dari Pemerintah Daerah.

Kue bagea yang ada di UKM Senang Hati bentuknya biasa dibuat kecil-kecil dengan warna cokelat dan teksturnya yang agak keras.

\section{b. Kapurung}

Kapurung merupakan sumber kandungan gizi seperti karbohidrat, protein, vitamin dan mineral. Sagu merupakan sumber karbohidrat dan campuran ikan atau daging sebagai sumber protein, dan aneka sayuran sebagai sumber vitamin dan mineral. Kapurung juga biasanya disajikan bersama bumbu-bumbu, seperti kacang tanah goreng yang dihaluskan, garam, dan penyedap rasa lainnya sebagai penambah selera.

Kendati kapurung ini termasuk makanan tradisional, tapi tidak membuat kapurung kalah oleh resep-resep modern. Terbukti di UKM Senang Hati, masih menyediakan kapurung bersama dengan kue-kue tradisional lainnya yang lebih modern.

\section{c. Sinole}

Selain kapurung ada juga makanan lain yang berbahan dasar sagu. Salah satunya adalah Sinole, olahan sagu dan parutan kelapa dengan citarasa yang sangat unik. Makanan ini adalah alternatif pilihan makanan berbahan dasar sagu agar kita tidak bosan menikmati kapurung saja.

Membuat sinole ternyata cukup mudah. Sagu mentah yang sudah dijemur disiapkan kemudian diayak hingga halus 
menjadi tepung.Setelah itu, siapkan kelapa parut dan masukkan ke dalam wajan panas. Selanjutnya, masukkan tepung sagu dan garam. Campur semua bahan menjadi satu dan merata dalam proses sangrai hingga sagu berwarna kecoklatan. Selanjutnya, Sinole sudah jadi dan siap untuk dihidangkan.

Sinole memiliki rasa yang unik, cita rasanya yang hambar berpadu dengan gurihnya parutan kelapa dapat terasa di lidah dengan cukup jelas. Tekstur lembutnya tepung sagu pun masih dapat terasa sekalipun makanan ini sudah dimasak hingga matang. Tekstur ini memang sengaja dipertahankan agar kenikmatan makanan ini pun tetap terjaga.Sinole cukup fleksibel untuk dinikmati, dapat menjadi pilihan makanan pokok seperti beras, atau dapat juga dinikmati sekedar sebagai teman minum teh saat pagi dan sore hari.

\section{Hasil Diversifikasi Pangan Berbahan Dasar Sagu \\ a. Bacci Laung}

Bacci laung adalah panganan khas Bugis Makassar Sulawesi Selatan yang terbuat dari olahan sagu. Bacci laung adalah nama kudapan dalam bahasa Bugis. Namun, warga Makassar lebih mengenalnya dengan nama sakko-sakko, yang artinya tersedak.

Bacci laung merupakan salah satu hasil olahan diversifikasi pangan yang disarankan penulis kepada UKM Senang Hati dan UKM tersebut bersedia menerima tawaran untuk menciptakan produk yang lebih beragam di dukung oleh banyak hal seperti sarana prasarana dan skill demi meningkatkan hasil olahan diversifikasi pangan berbahan dasar sagu.

Bacci laung berbahan dasar sagu dapat dinikmati kapan saja dan harus di dampingi teh, kopi, atau paling tidak air putih karena cemilan dalam segala suasana ini dapat membuat orang tersedak.
Proses pengolahan bacci laung masih secara tradisional. Prosesnya hanya mencampurkan pati sagu, kelapa parut, garam di aduk dalam wajan kemudian diangkat dan siap untuk di makan.

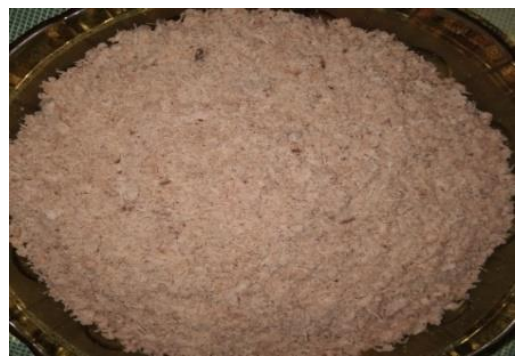

Gambar 1. Bacci Laung Olahan Diversifikasi dari Sagu

\section{b. Kerupuk Sagu}

Kerupuk sagu terbuat dari tepung sagu yang berasal dari pohon rumbia. Bentuk kerupuk sagu ini terbilang unik yang memiliki warna dasar abu-abu dan biasanya diberikan pewarna makanan yaitu warna merah dan hijau. Kerupuk sagu juga merupakan sumber karbohidrat sehingga diperlukan peningkatan nilai gizinya terutama kandungan proteinnya. Untuk itu diperlukan bahan tambahan seperti ikan, udang dan lain-lain sebagai alternatifnya.

Kerupuk sagu merupakan salah satu hasil olahan diversifikasi pangan yang di sarankan penulis kepada UKM Senang Hati dan UKM tersebut bersedia menerima tawaran penulis untuk menciptakan produk yang lebih beragam dan didukung oleh banyak hal seperti sarana prasarana dan skill demi meningkatkan hasil olahan diversifikasi pangan berbahan dasar sagu. Kerupuk sagu dapat di jadikan sebagai cemilan atau lauk.

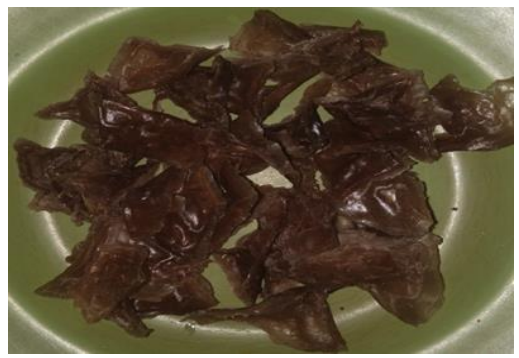

Gambar 2. Kerupuk Sagu 
Proses pengolahan kerupuk sagu ini masih dilakukan secara tradisional. Prosesnya hanya mencampurkan air panas/mendidih dengan pati sagu hingga membentuk adonan seperti kapurung, dicetak tipis-tipis, di jemur dibawah terik matahari kemudian di goreng menggunakan sumber panas langsung dalam minyak goreng mendidih.

\section{KESIMPULAN}

Kesimpulan dalam penelitian ini adalah diversifikasi pangan lokal berbahan dasar sagu di UKM Senang Hati Desa Poreang Kecamatan Tana Lili Kabupaten Luwu Utara adalah bacci laung dan kerupuk sagu.

\section{DAFTAR PUSTAKA}

Arikunto, S. 2013. Prosedur Penelitian : Suatu Pendekatan Praktik. Jakarta. Rineka Cipta
Flach, M. 1996. Sago Palm. International Plant Genetic Resourches Institute (IPGRI) Promoting The Concervation and Use Underulitized and Neglected Crops, 13. IPGRI, Italy and IPK Germany.

Hayati, N., R. Purwanti dan A. Kadir W. Preferensi Masyarakat Terhadap Makanan Berbahan Baku Sagu (Rottb) Sebagai Alternatif Sumber Karbohidrat Di Kabupaten Luwu Dan Luwu Utara Sulawesi Selatan. JURNAL Penelitian Sosial dan Ekonomi Kehutanan. 11 (1): 82 90

Sugiyono, 2012, Metode Penelitian Kuantitatif, Kualitatif, Deskriptif dan $R D$. Bandung: Alfabeta, cv. dililib 